\title{
Filosofia em "Tempos Sombrios": a leitura de Critão sobre Sócrates na Pólis diante das leis e da opinião da maioria - um olhar arendtiano
}

\author{
Philosophy in "Dark Times": the Criteo reading about Sócrates in \\ the Pólis in front of laws and the majority opinion - \\ an arendtian look
}

Daner Hornich

https://orcid.org/0000-0003-2515-8069 - E-mail: danerhornich@hotmail.com

\begin{abstract}
RESUMO
As questões postas para Sócrates consistem em "guiar-se" pelo conselho dos outros para salvar a sua vida; para não se privar dos amigos e muito menos legar infelicidade para os que dispõem de dinheiro para ajudá-los entre si quando necessário: pois, qual é o valor do dinheiro quando a amizade é colocada em jogo? Sócrates não se guia pelas cabeças alheias, pois examina as próprias questões (colocadas por ele ou outros) como um provocador, ou parteiro das reflexões e pensamentos. Isso porque as respostas indicadas por Sócrates parecem um desvio de rota, ao começar um diálogo sobre a opinião da maioria, que, para Critão, é ponto significativo, e para Sócrates não, pois não devemos nos preocupar com a opinião da maioria, mas com as considerações dos melhores.
\end{abstract}

Palavras-chave: Sócrates. Critão. Tempos sombrios. Opinião da maioria. Hannah Arendt.

\begin{abstract}
The issues put to Socrates consist in "guiding" by the advice of others to save his life; not to deprive himself of friends, and much less to transmit unhappiness to those who have money to help each other when necessary: after all, what is the value of money when friendship is put at
\end{abstract}


risk? Socrates does not guide himself through the heads of others, he examines his own questions (posed by him or others) as a challenger, or a inductor of reflections and thoughts. This happens because his answers seem to be a deviation of route, beginning a dialogue based on the majority opinion, what for Criteo, it is fundamental, for Socrates it is not, so we should not be worried with the majority opinion, however, with the best considerations.

Keywords: Socrates. Criteo. Dark times. The majority opinion. Hannah Arendt.

\section{Introdução}

Filosofia em "tempos sombrios" - termo emprestado do poema de Bertold Brecht (1898 - 1956) - "A posteridade" ou "Aos que virão depois de nós" (ARENDT, 1987, p. 7); do qual Hannah Arendt se utilizou para clarear a vida dos homens de ação que ganharam visibilidade e notoriedade em tempos perigosos, difíceis e caóticos - tornou-se para nós uma luz de vela para clarear os tempos turbulentos que vivemos em nossa sociedade democrática ${ }^{1}$. Pensar a perspectiva democrática ou a vida política da nossa sociedade a partir da "leitura de Critão sobre Sócrates na Pólis diante das leis e da opinião da maioria na perspectiva do olhar da Hannah Arendt"é pensar o conflito entre o filósofo e a pólis². Sobre esse assunto vale o argumento de Richard R. Oliveira: "Hannah Arendt, com argúcia que lhe é característica, foi uma das poucas autoras contemporâneas, ao lado de Strauss, a perceber claramente esse ponto, ..." (OLIVEIRA, 2011, p. 50). Ou seja:

O abismo entre filosofia e política abriu-se historicamente com julgamento e a condenação de Sócrates, que constituem um momento decisivo na história do pensamento político, assim como o julgamento e a condenação de Jesus constituem um marco na história da religião. Nossa tradição de pensamento político teve início quando a morte de Sócrates fez Platão desencantar-se com a vida da polis e, ao mesmo tempo, duvidar de certos princípios fundamentais dos ensinamentos socráticos [...]. A ênfase de Sócrates em sua defesa perante os cidadãos e juízes atenienses estivera em que o seu comportamento tinha vista o bem da cidade. No Critias, ele havia explicado a seus amigos que não podia fugir, mas, ao contrário, deveria - por razões políticas - ser condenado à morte. Ao que parece, não foi apenas os seus juízes que ele mostrou-se incapaz de persuadir; tampouco conseguiu convencer seus amigos. Em outras palavras, a cidade não precisava de um filósofo, e os amigos não precisavam de argumentação política. Isso é parte da tragédia atestada pelos diálogos de Platão. (ARENDT, 1993b, p. 92).

As razões políticas e a tragédia atestada da polis ateniense ao julgar e condenar Sócrates nos remete pensar neste artigo a terminologia dos "tempos sombrios", para apresentar sobre o prisma da Hannah Arendt Sócrates pelas mãos de Platão e no texto intitulado Critão ${ }^{3}$, pois a nossa proposta é pensar sobre a vida pública a partir das leis da cidade que formam os seus ci-

\footnotetext{
${ }^{1}$ Elegemos um presidente com posturas ditatórias para governar o Brasil em 2019.

2 Pensamos que o conflito entre o filósofo e a vida política são assuntos recorrentes nos nossos tempos. Sobre esse assunto analisar a postura do atual governo em relação ao ensino de filosofia nas escolas e nas universidades.

3 Segundo Franco Trabattoni a obra de Platão intitulada Critão (Criton) se insere nos diálogos da "Apologia de Sócrates":_ "..., onde é posto em cena Sócrates que se defende diante dos juízes; Críton, Sócrates no cárcere rejeita a proposta de fuga que Ihe faz Críton; Eutífron, Lísis, Cármides, Laques, Hípias Maior, Mênon, primeiro livro d’A República: em todos esses diálogos, Sócrates conduz as investigações sobre um conceito de caráter geral, refutando as respostas de seus interlocutores. Esses conceitos são, na respectiva ordem, o santo (o sagrado), a amizade, a temperança (sophrosyne), a coragem, a beleza, a virtude e a justiça; ĺon, que trata da poesia; Alcibíades I, sobre a primazia da alma e sobre a educação interior; Hípias Menor, onde se faz um confronto entre Aquiles e Odisseu; Górgias, no qual Sócrates dialoga com Górgias, Polo e Cálicles a respeito da natureza da retórica e sobre a felicidade do justo; Protágoras, Sócrates duela com o sofista sobre a natureza da virtude e sobre a possibilidade de educar à virtude; Eutidemo, no qual Platão contrapõe o modo socrático de fazer filosofia aos truques dialéticos dos sofistas menos sérios; Menêxeno, provavelmente uma paródia da retórica tradicional (TRABATTONI, 2017, p. 14-15).
} 
dadãos em meio à posição e o alvoroço das massas ${ }^{4}$, que puxa o cabo de guerra para um lado ou para outro das opiniões que são postas no jogo da vida e dos interesses que podem ou não promover o bem de todos. Contudo, como argumenta Luciano Canfora;

Não se pode esquecer que o processo contra Sócrates foi, na verdade, um processo acima de tudo político, embora venha oleograficamente transfigurado na habitual leitura que se faz dele: basta considerar que o acusador principal, que teve papel decisivo para levar os juízes à condenação, foi um político de primeira grandeza como Anito, respeitável expoente da democracia restaurada. O próprio Sócrates, segundo discurso do tribunal, aponta que o fato de Anito ter assumido em pessoa o papel de acusador teve um peso decisivo em sua condenação. (CANFORA, 2015, p. 76).

Assim, como homem de reflexão e ação, Sócrates ganha visibilidade pela sua coerência de pensamento e ação ao guiar pelos labirintos do mundo sombrio de Atenas, com as suas leis e costumes que formavam e condenavam o homem livre e cidadão ${ }^{5}$, quando o obscurantismo das mentes e corpos não possuíam a abertura, finura e a leveza da luz da razão e dos sentidos para imaginar e pensar criteriosamente o novo no tempo 6 . Podemos dizer que esse "novo no tempo", como demonstra Pierre Hadot é a intervenção do filósofo, que como Sócrates "consistira em permitir seu interlocutor 'realizar"' o seu verdadeiro papel na polis, isto é o "o verdadeiro bem, o verdadeiro valor" - que é "o amor do bem" (HADOT, 1999, p. 62). Pois:

O conteúdo do saber socrático é, no essencial, o "valor absoluto da intenção moral" e da certeza de que procura a escolha desse valor. Evidentemente, a expressão é moderna. Sócrates não teria empregado. Mas ela talvez seja útil para ressaltar todo o alcance da mensagem socrática. Pode-se dizer que um valor é absoluto para um homem quando ele está prestes a morrer por esse valor. É precisamente a atitude de Sócrates, quando se trata do "que é o melhor", isto é, da justiça, do dever, da pureza moral. Ele repete várias vezes na Defesa: prefere a morte e o perigo a renunciar a seu dever e a sua missão. (HADOT, 1999, p. 63).

\section{Segundo Hadot no Critão (ou Críton),}

[...], Platão imagina que Sócrates faz falar as leis de Atenas, que o fazem o compreender que, se quiser evadir-se e escapar à sua condenação, prejudicará toda a cidade, dando o exemplo de desobediência a suas leis: ele não deve por sua própria vida acima do que é justo [...]. A seus olhos, há apenas um mal, a falta moral, há apenas um bem, um único valor, a vontade de fazer o bem, o que supõe que ele não recusa examinar sem cessar e rigorosamente sua maneira de viver, a fim de ver se ela é sempre dirigida e inspirada por essa vontade de fazer o bem. Pode-se dizer, até certo ponto, que o que interessa a Sócrates não é definir o que pode ser um conteúdo teórico e objetivo da moralidade: é necessário saber se se quer real e concretamente fazer o que se considera justo e bom: como se deve agir. (HADOT, 1999, p. 63-64).

\footnotetext{
4 Sobre o assunto conferir o capítulo oitavo: "O saber da pólis". (BRISSON, 2012).

5 "Na nódıc circulam continuamente mensagens destinadas a chegar a todos os cidadãos e a uniformizar seus pontos de vistas e as suas opiniões. Está em vigor aquele regime que nas Leis (III, $700 \mathrm{~A}$ ss) Platão define como 'teatrocracia', para mostrar como no âmbito político a massa, assim como faz no teatro, se expressa apenas através de gritos de aprovação ou de desaprovação, de modo totalmente irracional. Nesta situação, os poucos que procuram conservar a própria autonomia de opinião são punidos e até levados à morte: clara aqui a referência à condenação de Sócrates, que assumira constantemente um papel crítico diante dos cidadãos e da gestão política." (GASTALDI, 2015, p. 157).

6 A questão do obscurantismo pode ser relaciona ao suposto "mundo da caverna" e o tema correlato pode ser encontrado na seguinte referência de Silvia Gastaldi:"..., no interesse coletivo, o filósofo é obrigado a governar, a redescender àquela caverna - que é um emblema da cidade atual, o lado escuro em que domina a ignorância da verdade e dos valores - da qual a obra educativo-formativa dos outros filósofos o libertou: trata-se de uma verdadeira coação, como Platão afirma repetidamente, não obstante

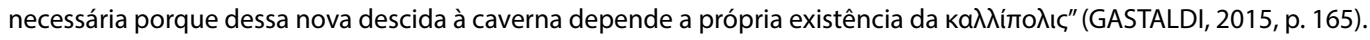


A questão como se deve agir é um ponto de encontro com a reflexão que pretendemos realizar ao pontuar a obra de Platão, Critão (ou Críton) sob o olhar atento de Hannah Arendt, por meio das seguintes perguntas: dá vontade de fazer o bem? Por fim, o que é considerarmos justo e bom quando devemos agir para o bem comum? Essas perguntas podem nos guiar na leitura que vamos realizar do Critão (Críton) sob o olhar entrecruzado da Hannah Arendt sobre as questões postas por Platão e lembradas por Hadot ao argumentar que:

Encontramos aqui, talvez ainda confuso e indistinto, um esboço da ideia a ser desenvolvida mais tarde, em outra problemática, por Kant: a moralidade constitui-se na pureza da intenção que dirige a ação, pureza que consiste precisamente em conferir um valor ao bem moral, renunciando totalmente ao próprio interesse. Tudo leva a pensar, por outro lado, que esse saber jamais pode ser adquirido. Não é somente aos outros, mas a si mesmo que Sócrates não cessa de submeter a exame. A pureza da intenção moral deve sem cessar ser renovada e restabelecida. A transformação de si jamais é definitiva. Exige uma perpétua reconquista. (HADOT, 1999, p. 65).

Tendo em vista essas colocações preliminares, podemos argumentar que o nosso ensaio passará por Kant, ao pensar a intenção das nossas ações acima dos nossos próprios interesses e pelas reflexões da Hannah Arendt, ao refletir sobre a obra de Platão, Critão (ou Críton). Contudo, deixamos claro que não somos especialistas em Platão, muito menos carregamos sobre os ombros o mandarinato das obras canônicas de Platão a ponto de fazer uma hermenêutica ou exegese fiel aos interpretes autorizados das obras platônicas, ou seja, não seremos originais a ponto de trazer bibliografias atualíssimas e adequadas ao ensaio filosófico sobre Platão, mas leitores de Platão, nós vamos transitar por sua obra, como aqueles transeuntes que, de tempos e tempos, refletem seus textos com a intenção de pincelar reflexões para iluminar os nossos "tempos sombrios" que se manifestam por meio da mentira deliberada, adulteração dos fatos e da opinião articulada pela mídia que presta um desserviço a população ${ }^{7}$. A mídia lembra os sofistas que eram os verdadeiros mercadores das palavras ao léu. Neste sentido, podemos verificar o argumento da Hannah Arendt sobre o problema da opinião:

Intimamente ligada à dúvida de Platão quanto à validade da persuasão está a sua enérgica condenação da doxa, a opinião, que não só atravessou suas obras políticas, deixando uma marca inequívoca, como tornou-se uma de suas pedras angulares do seu conceito de verdade. A verdade platônica, mesmo quando a doxa não é mencionada, sempre é entendida como justamente o oposto da opinião. O espetáculo de Sócrates submetendo sua própria doxa às opiniões irresponsáveis dos atenienses e sendo suplantado por uma maioria de votos, fez com que Platão desprezasse as opiniões e ansiasse por padrões absolutos. Tais padrões, pelos quais os atos humanos poderiam ser julgados e o pensamento poderia atingir alguma medida de confiabilidade, tornaram-se, daí em diante, o impulso primordial de sua filosofia política influenciando de forma decisiva até mesmo a doutrina puramente filosófica das ideias. (ARENDT, 1993b, p. 92).

Segundo Hannah Arendt, o problema da verdade e da opinião não instaurou só o problema entre o filósofo e a polis, mas uma atitude anti-socrática, pois o fracasso de Sócrates diante do seus concidadãos no julgamento, isto é, de não conseguir convencê-los, fez com que Platão percebe o perigo que o filósofo corria na cidade diante do seus cidadão que vivem segundo os ares das opiniões e não da verdade que proporcionam princípios regulativos para os cidadãos da polis, pois "a filosofia se define, na perspectiva platônica, não como a posse de uma doutrina ou como um mero sistema abstrato das ideias, mas como uma atividade ou práxis libertadora"

\footnotetext{
7 Sobre esse assunto ler o ensaio: "A mentira na política: considerações sobre os documentos do Pentágono." (ARENDT, 1999).
} 
(OLIVEIRA, 2011, p. 30). Essa práxis libertadora é dinamizada pedagogicamente pelo exercício da visão que aprende de modo paciente, investigar a vida humana na esfera da vida política.

Platão narra na obra intitulada Critão, que Sócrates foi condenado pelos juízes da Pólis ateniense e está na prisão ${ }^{8}$. Na narrativa platônica, Critão vai visitar Sócrates para tentar convencê-lo de fugir da prisão e abandonar Atenas para viver em outro lugar qualquer do mundo antigo. Contudo, Sócrates não adere a posição de Critão, mas vai até as últimas consequências em relação a sua posição e postura (hexis) diante da Pólis. Demostrando, com isso a sua coerência de pensamento e ação. Sobre essa questão podemos elucidar que a situação de Anaxágoras e Aristóteles é oposta à postura de Sócrates, como argumentou Luciano Canfora:

Anaxágoras livrou-se da morte, Sócrates quis enfrentá-la - não porque estivesse cansado da vida, como Xenofonte afirmou de forma tola em sua "Apologia de Sócrates." Anaxágoras não se tornou, nos séculos seguintes, um símbolo; Sócrates, sim, justamente por causa de sua decisão de sofrer até as últimas consequências o erro de seus condenadores. Aristóteles também se deparou, décadas mais tarde, com a mesma ameaça, e preferiu agir como Anaxágoras, e não como Sócrates, "para evitar" - como disse - "que os atenienses pecassem mais uma vez contra a filosofia". Os atenienses eram assim mesmo, e Aristóteles, que além de tudo era meteco, não tinha a menor intenção de oferecer-se como vítima sacrifical ao obscurantismo vigente (e às vezes predominantes) na cidade que Tucídides definiu, pela boca de Péricles, em seu célebre epitáfio, como"escola da Héleade."(CANFORA, 2007, p. 17).

O "ofício do filósofo"9 é uma atividade altamente perigosa, pois a atividade do filósofo é de ser um contraponto aos dilemas e aos problemas instaurados pelos cidadãos na Pólis, de forma crítica, criativa, racional e conflituosa, pois tal postura contestatória e de exame minucioso das questões posta sobre a "mesa do diálogo" da "ágora" (áyopá); e do mercado livre pro-

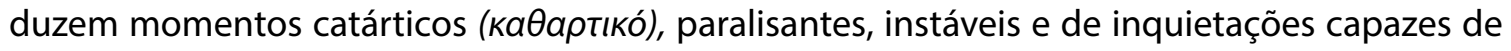
provocar afetações violentas contrárias aqueles que a provocaram com os seus ferrões o seu despertar para a vida e a vida bem vivida na Pólis. ${ }^{10}$ Sobre a virulência daqueles que não suporta a vida tumultuada pelo exame crítico do pensamento, vale a pena conferir a reflexão de Luciano Canfora:

Friso que a condenação à morte não chegou de improviso. Mais de vinte anos antes, Aristófanes havia pensado em fazer rir o seu público com prazer ao colocar em cena o assalto de um grupo de fanático incendiário à casa de Sócrates. O efeito cômico nascia, entre outras coisas, do fato de os assaltantes mostrarem-se totalmente insensíveis aos gritos desesperados daqueles que, dentro da casa segundo a ficção cênica, morriam sufocados na fumaça e nas chamas. (CANFORA, 2003, p. 18).

\footnotetext{
${ }^{8}$ Segundo Luciano Canfora em seu artigo - "Pode a maioria estar errada?" Argumenta que: "Os quinhentos juízes que condenaram Sócrates constituíam uma amostra significativa da cidadania ateniense. Não deixa de ser útil relembrar o mecanismo por meio do qual eles eram escolhidos. O ponto de partida para a formação de um tribunal era uma lista de seis mil cidadãos, provavelmente voluntários, redigida anualmente: tratava-se de simples cidadãos e não de peritos em direito. Eram cerca de um quarto do corpo cívico, se considerarmos que, num censo realizado mais ou menos oitenta anos após esse processo, os cidadãos atenienses somavam ao todo 21 mil. O número de jurados que compunha cada um dos tribunais variava de acordo com a importância da causa: de qualquer modo, trata-se sempre de algumas centenas. No caso do processo de Sócrates, podemos presumir com facilidade que houvesse quinhentos juízes, número provavelmente habitual. Cada Júri gozava de plena autoridade e competência. Os cidadãos-juízes recebiam um salário de três óbolos diários, ou seja, o necessário para viver. Por isso, principalmente aqueles menos favorecidos desejavam ser sorteados. Era um trabalho muito satisfatório, mesmo com o modesto pagamento. Grande parte dos negócios públicos terminava no tribunal e, assim sendo, os seis mil cidadãos-juízes deliberavam sobre a vida da comunidade no tribunal tanto quanto, ou talvez até mais, que nas sessões da assembleia popular. Chegava-se ao veredicto após uma seqüência de etapas: num primeiro momento, era discutida a culpa ou a inocência; em seguida, se o réu fosse considerado culpado, discutia-se o caráter da pena. Tanto na primeira como na segunda discussão, o acusado tinha permissão." (CANFORA, 2007, p. 11-12).

9 Título do livro do Luciano Canfora. (CANFORA, 2003).

${ }^{10}$ Nas belas palavras da Hannah Arendt: "Sócrates é um moscardo: ele sabe ferroar os seus cidadãos que, sem ele, vão 'continuar a dormir pelo resto de suas vidas', a menos que alguém venha despertá-los. E para que os despertar? Para o pensamento e para a investigação, uma atividade sem a qual, a seu ver, a vida não valia a pena e nem sequer era totalmente vivida." (ARENDT, 1995, p. 130).
} 
Os ataques "obscurantistas dos atenienses" aos filósofos na perspectiva acima demonstram o grau de barbárie ${ }^{11}$ que podemos chegar ao induzirmos as pessoas, se sentirem em estados de prazer e gozo da desgraça alheia, com posturas fanáticas, de assalto e de insensibilidade, por não tolerarem o estilo diferente daqueles que pensam formas de vida distintas e diferenciadas, pois tais homens de pensamento aguçado colocavam tudo em suspeição (CANFORA, 2003, p. 20). Nas palavras de Hannah Arendt:"Sócrates, sabendo que não sabemos, recusa-se contudo a deixar tudo por isso mesmo e desistir de suas próprias perplexidades; e, como a arraia elétrica, permanece paralisando e paralisa os que com ele entra em contato" (ARENDT, 1995, p. 130). Tal atitude impõe aos cidadãos a possibilidade de pensar o sentido da vida na Pólis pela "educação do pensamento", como argumentou Platão na República:

E se o forçam a fitar a própria luz, não ficarão os seus olhos feridos? Não tirará dela a vista, para retornar às coisas que pode olhar, e não crerá que estas são realmente mais distintas do que as outras que lhes são mostradas? - Seguramente. - E se - prossegui - o arrancam à força de sua caverna, o compelem a escalar a rude e escarpada encosta e não o soltam antes de arrastá-lo até a luz do sol, não sofrerá ele vivamente e não se queixará destas violências? E quando houver chegado à luz, poderá, com os olhos completamente deslumbrados pelo fulgor, distinguir uma só das coisas que agora chamamos de verdadeiras? Não poderá respondeu; - ao menos no começo. - Necessitará, penso, de hábito para ver os objetos da região superior. Primeiro distinguirá mais facilmente as sombras, depois as imagens dos homens e dos outros objetos que refletem nas águas, a seguir os próprios objetos. Após isso, poderá, enfrentando a claridade dos astros e da lua, contemplar mais facilmente durante a noite os corpos celestes e o céu mesmo, do que durante o dia o sol e sua luz. (PLATÃO, 515e; 516a-b).

Pensando no sentido da vida na Pólis e da "educação do pensamento", podemos vislumbrar que o processo educacional em Platão é uma atividade violenta, pois exigi uma guinada no comportamento do sujeito que retirado da sua posição e posto numa outra situação que exigirá esforço e hábito para escalar os degraus do conhecimento para desvelar a verdade que se manifesta na distinção, na claridade e na contemplação dos objetos que brilham aos nossos

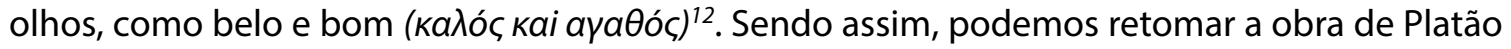
intitulada Critão, para verificar que o diálogo é repleto de elucidações, seja do tempo da "hora dada" e medida pela "aurora" que "vem raiando" e da "hora de chegada", seja do guarda corrompido que cede passagem para Critão entrar na prisão e visitar Sócrates, por ser alguém "conhecido" e "feito algumas gentilezas". Não é Sócrates que é conhecido por fazer gentileza, mas Critão. Podemos notar, que a medida do tempo se "des-vela" nas tramas da "aurora" que vem raiando, metáfora do sol, da luz, da verdade, do conhecimento e da ciência - (PLATÃO, A República, 509a). Como elucidou Platão no livro A República:

Ora, aquilo que difunde a luz da verdade sobre os objetos do conhecimento e confere ao sujeito conhecedor a capacidade de conhecer, é a ideia do bem; visto que ela é o princípio da ciência da verdade, podes concebê-la como objeto do conhecimento, porém, por mais bela que sejam estas duas coisas, a ciência e a verdade, não te enganarás de modo algum,

\footnotetext{
11 "...: eles experimentam quanto é'doce e boa' a posse do saber; ao mesmo tempo veem a "loucura da maioria", a irracionalidade dos cidadãos que dá lugar à injustiça, e preferem ficar distante disso. A vida política que se realiza na cidade atual não tem em si afirma Platão - nada de positivo, e sobretudo o verdadeiro filósofo não tem nenhuma possibilidade de melhorar a situação. A metáfora usada aqui é comparada a um homem que se depara com um bando de animais selvagens e não pode contar com nenhuma ajuda (VI, 496 D) (GASTALDI, 2015, p. 157).

12 "Como no Críton, também no Górgias Sócrates se propõe como exemplum de um comportamento marcado pela absoluta obediência ao $\lambda$ oyoç e aos seus ditames: o diálogo pretende representá-lo como modelo de uma disposição que segue as argumentações racionais, aceita seus resultados e faz delas máximas norteadoras das ações. Sócrates não está disposto a renunciar às argumentações que julga melhores: influências externas ou emoções não tem efeito sobre a sua relação com as argumentações racionais, nem sobre seu comportamento, como mostra de maneira icástica também o Fédon" (ERLER, 2015, p. 124).
} 
pensando que a ideia do bem é distinta e as supera em beleza; como, no mundo visível, é certo pensar que a luz e a vista são semelhantes ao sol, mas errado acreditar que sejam o sol, do mesmo modo, no mundo inteligível, é justo pensar que a ciência e a verdade são, ambas, semelhantes ao bem, mas falso acreditar que uma ou outra seja o bem; a natureza do bem há de ser considerada muito mais preciosa. (PLATÃO, A República, 509a).

A noção do objeto do conhecimento que se fundamenta na busca da ciência ${ }^{13}$ e da verdade pode ser encontrada na narrativa Platônica do Critão pela reflexão que nos conduz ao viver bem e não ao simples viver que se pontuam pela falta de reflexão, sensações e opiniões (PLATÃO, Teeteto 210a). Sendo assim, podemos continuar seguindo a perspectiva platônica da narrativa de Critão para indicar outras passagens significativas, como a cena do Sócrates dormindo o "sono dos deuses" que Critão teme interromper o seu último sono ou o "despertar interrogativo" de Sócrates que como num raio de luz (metáfora da luz novamente como indicação do uso da razão e dos sentidos) pergunta ao seu amigo Critão: - "Mas, afinal, por que vieste tão cedo?"

Aqui começam algumas questões problemáticas do diálogo entre Sócrates e Critão para delinear os critérios da vida dos homens no mundo da Pólis na sua relação tênue com a filosofia e os filósofos no trato com as leis ${ }^{14}$, o bem comum e o bem público, a verdade e a opinião, a corrupção, o dinheiro e a dignidade dos homens, a educação, os filhos, os pais e a Pólis, a coerência e o exame crítico das palavras e ações, a felicidade e a infelicidade, bem e mal, sem deixar de falar da postura em não ceder à opinião da maioria e não trair a si mesmo para se conformar a opinião dos outros, como um insensato ${ }^{15}$. Neste sentido, podemos argumentar com Hannah Arendt que:

A principal distinção entre persuasão e a dialética é que a primeira dirige-se sempre a uma multidão (peithei' ta pléthé), ao passo que a dialética só é possível entre dois. O erro de Sócrates foi dirigir-se a seus juízes de forma dialética, motivo pelo qual não pôde persuadi-lo. Por outro lado, uma vez que respeitou os limitações inerentes à persuasão, sua verdade tornou-se uma opinião entre as opiniões, sem mais valor que as não-verdade dos Juízes. Sócrates insistiu em discutir o assunto com seus juízes do mesmo modo que falava de qualquer outra coisa, quer com os cidadãos atenienses, individualmente, quer com seus alunos; acreditava que pudesse chegar por esse caminho a alguma verdade e que dela pudesse persuadir os outros. A persuasão, entretanto, não vem da verdade, mas das opiniões, e só a persuasão leva em conta e sabe lidar com a multidão. (ARENDT, 1993b, p. 96).

O pressuposto fundamental é que filósofo não é um "doutrinador", muito menos um "mercador de palavras" como os sofistas que vendem e mercadejam conhecimento de cidade em cidade (PLATÃO, Protágoras 313a-d), muito menos um adulador das multidões que se com-

\footnotetext{
13 “Na República, por exemplo, depois de expor a famosa analogia do Sol (508a-509b), que distingue claramente os mundos visível e inteligível, Sócrates apresenta a não menos famosa analogia da linha dividida (509d-511e), que introduz uma gradação nesses mundos, ao distinguir dois níveis em cada um: o mundo visível se estrutura em imagens e objetos sensíveis, ao passo que no mundo inteligível se 287 PRINCÍPIOS distinguem o nível dos entes matemáticos e o das Ideias. Em exata correspondência ao plano do ser, o plano do conhecimento também se estrutura em dois níveis: o da imaginação e o da crença constituem o mundo da opinião, enquanto o do conhecimento e o da intelecção estruturam o mundo da ciência." (PERINE, 2018, p. 286-287).

14 "[...] o diálogo As Leis oferece um inovador projeto de cidade, também múltipla e diversificada, como forma de assegurar a unidade política e ética. Assim como cada individuo constitui uma unidade (Leis $644 \mathrm{c}$ ), a cidade a ser edificada, como representativa da liberdade e da virtude, será aquela capaz de conciliar múltiplos modelos de organização e legislação (Leis 701e). A justa medida e o equilíbrio que garantem a unidade da pólis e de seus cidadãos, será viável se for garantida a capacidade de conciliar os vários modos de representação da vida na cidade, com confiança na unidade de sua legislação e governo; cidades sabiamente orientadas para o bem da coletividade (Leis 715 b)." (FILHO, 2014, p. 83).

${ }^{15}$ Como argumenta Vegetti: "A injustiça é doença da alma, que a torna pior, isto é, infeliz; o justo, mesmo que seja submetido a perseguições injustas, guarda aquela serenidade e aquele equilíbrio interior de que, como se disse, depende a felicidade. Em todo o caso, assevera Sócrates, 'a justiça paga', recompensa o homem justo com uma boa vida." (VEGETTI, 2018, p. 314).
} 
porta como criança ${ }^{16}$ pela adulação e oratória da "pior espécie"17 (PLATÃO, Górgias 502b - 503ab). Como escreveu Luciano Canfora:

Em Górgias, quem fala é Sócrates; ele é que descreve os grandes corruptores da política. Segundo o seu juízo, há quatro na história ateniense: Milcíades, Temístocles, Péricles e Címon. Platão, como sempre, é impiedoso em sua crítica radical do sistema político ateniense. Os personagens que aqui condena em bloco também são rivais entre si; no entanto, condena a todos eles como corruptores do povo. Pois fizeram o que Tucídides nega que Péricles tenha feito: falar pròs hedonén, 'para agradar' ao povo. Platão censura em Péricles justamente a oratória demagógica, o agradar à assembleia, e por isso, diz o Sócrates de Górgias, tornou os atenienses piores do que eram'. Não só o condena por essa oratória demagógica, por esse agradar ao povo, mas também porque foi o primeiro a introduzir um salário para as tarefas públicas. O salário para ocupar um cargo, que é a viga mestra do mecanismo democrático ateniense. (CANFORA, 2015, p. 131).

Sendo assim, podemos argumentar que o Sócrates de Platão é um crítico da democracia ateniense em "oposição à opinião pública", como sublinhou Hannah Arendt:

Sócrates não foi membro de qualquer seita e não fundou nenhuma escola. Tornou-se a figura do filósofo porque desafiou todos os que vinham ao mercado - porque estava completamente desprotegido, aberto a todos os questionadores, a todos os que dele exigissem prestação de contas ou vivencia daquilo que dizia. As escola e seitas não são iluministas (na linguagem de Kant) porque dependem das doutrinas de seus fundadores. Desde a Academia de Platão, elas se encontram em oposição à 'opinião pública', a sociedade em sentido amplo, ao 'eles', mas isso não significa que não se amparem em nenhuma autoridade. O modelo é sempre o da escola dos pitagóricos, cujos conflitos podiam ser resolvidos por meio do apelo pela autoridade do fundador: ao autos epha, ao ipse dixit, ao'ele próprio disse isso'. Em outras palavras, o dogmatismo impensado da maioria é contraposto aos seletos dogmatismos, igualmente impensado, da maioria. (ARENDT, 1993a, p. 50-51).

A questão fundamental é não se dobrar a multidão doutrinada - imagem da criança ${ }^{18} \mathrm{e}$ muito menos se conformar a opinião dos outros ${ }^{19}$, ou seja, os pressupostos de tal posicionamento contrário aos "muitos", nos mostra:

Platão, crítico de toda a tradição democrática ateniense fundada no pacto entre senhores e o povo, que lhe parece apenas fonte de corrupção e má política, não só não hesita em colocar Péricles entre os governantes que arruinaram a cidade (Górgia 515), como também, no Menexeno, parafraseia com ferocidade alguns pontos cardeais do discurso para sepultálo sob uma mortalha de sarcasmo. (CANFORA, 2015, p.17).

\section{Com efeito, pode se ler que as classes altas e dominantes de Atenas:}

[...] constitui no fato de ter aceitado o desafio da democracia, isto é, a convivência conflituosa com o controle obsessivo cerrado e não raro obscurantista do "poder popular": de tê-lo aceitado mesmo destacando-o, como se evidencia nas palavras de Alcibíades, exilado em Esparta pouco tempo antes, quando a democracia como 'uma loucura universalmente

\footnotetext{
16 “A metáfora da 'criança no homem' desempenha, portanto, o papel de explicar a fonte do mal - as paixões - sem que se necessite perguntar com precisão se tal fonte se localiza no corpo ou no âmbito da alma. Seja qual for a colocação que se deseje atribuir á 'criança ao homem', com esta metáfora é introduzida uma instância que não é localizada com mais exatidão, mas que ainda assim é capaz de representar um obstáculo para alma racional." (ERLER, 2015, p. 132).

17 "Para Sócrates, a retórica é tão somente uma forma de adulação, que corrompe, em vez de educar, os cidadãos e da qual os políticos se servem em seu exclusivo interesse." (GASTALDI, 2015, p. 158).

${ }^{18}$ Sobre esse assunto conferir o artigo O caldeirão de Média. (ROMANO, 2001).

19 'A filosofia - afirma Sócrates - 'diz sempre a mesma coisa' (482 A), ou seja, possui seu conteúdo preciso e propõe ensinamentos que nunca mudam, ao passo que a atividade do político, se deseja ter sucesso, deve adequar-se às opiniões sempre mutáveis dos cidadãos às disposição de ânimo da Assembleia. (GASTALDI, 2015, p. 158).
} 
.reconhecida como tal. [...]. Uma elite 'descrente' que escolheu se pôr à frente de uma massa popular 'carola', mas bem-intencionada, como a qual contraria em termos políticos por meio do mecanismo delicado e imprevisível da "assembleia". (CANFORA, 2015, p. 20).

Voltando ao Critão, temos o cenário do diálogo, mediado pela bela e graciosa mulher de vestes branca. Será a deusa da Justiça? Veste branca lembra transparência (PLATÃO, Górgias 526e) e a beleza é tudo aquilo que brilha aos nossos olhos por proporcionar o bem e graça às "palavras e ações" imortalizadas no tempo e no espaço da história e do pensamento dos homens no mundo pelo princípio da unidade da verdade e do $\operatorname{ser}^{20}$. Nas palavras de Platão temos o seguinte diálogo para ilustrar as "nossas ideias" que demarcam a relação entre a filosofia e a polis na construção da noção de tempo ${ }^{21}$, crise e oportunidade:

Critão - Sim, muito, como se vê. Mas, meu caro Sócrates, ainda é tempo de seguires o meu conselho e de te salvares. Porque, se vieres a morrer, não constituirá isso uma infelicidade apenas para mim. Além de ver-me privado de um amigo nas tuas condições, como nunca mais poderei encontrar outro, muita gente que nem a ti nem a mim conhece suficientemente há de acreditar que eu poderia ter-te salvado, se me dispusesse a despender algum dinheiro, mas que me descuidei. E que pior fama poderá ter alguém do que a de dar mais valor ao dinheiro do que aos amigos? A maior parte das pessoas não se convencerá de que tu mesmo te recusaste a sair daqui, apesar de todo o nosso trabalho nesse sentido. Sócrates - E que nos importa a nós, meu caro Critão, a opinião da maioria? Os melhores, cujo voto é o único que pesa, não porão em dúvida que tudo se passou como realmente se passou. Critão Mas, como estás vendo, Sócrates, é preciso tomarmos também em consideração a opinião da maioria. O presente caso, justamente, nos mostra por maioria muito clara que o grande número é capaz de causar mal não pequeno, senão mesmo o maior de todos, quando alguém é vítima de calúnia. Sócrates - Quem nos dera, Critão, que eles fossem capazes de causar o maior mal, porque assim estariam também em condições de fazer o maior bem. Coisa, nem para outra. Sem a capacidade de deixar alguém sensato ou insensato, tudo o que fazem é por mero acaso. (PLATÃO, 2007, 64-65 ou 44c-d).

As questões postas para Sócrates é de "guiar-se" pelo conselho dos outros para salvar a sua vida, para não privar-se dos amigos e muito menos legar a infelicidades para os mesmos que dispõem de dinheiro para ajudá-los entre si quando necessário, pois o que é o valor do dinheiro quando a amizade é colocada em jogo? Sócrates não se guia pelas cabeças alheia, pois examina as próprias questões interrogadas por ele ou outros como um provocador ou parteiro de reflexões e pensamentos ${ }^{22}$ (ARENDT, 1995, p. 134). Podemos recordar do texto: O que é o esclarecimento? de Immanuel Kant (2008) sobre o uso da própria razão pela própria cabeça e não com a cabeça dos outros, para buscar a saída (movimento, podemos ver a riqueza do verbo sair de uma situação para outra no processo de mudança em movimento pelo uso entendimento) da menoridade ${ }^{23}$. Na interpretação Pierre Hadot:

\footnotetext{
20 “O objectivo perseguido pelo texto platónico é mostrar que todos devem orientar a sua acção pela justiça. Só aí poderão encontrar a sua plena realização como homens uma vez que a arete humana e a arete política coincidem, segundo a posição platónica. A filosofia cabe o especial privilégio de contribuir para que esse telos seja alcançado com maior ou menor perfeição em cada caso." (MARTINS, 1995, p. 395).

${ }^{21}$ Vale lembrar que a noção de tempo para Platão acerca do tempo: “... liga-se às revoluções completas dos astros, cujo número considerado ao infinito é a imagem da eternidade. Por isso Aristóteles dirá, primeiro, que uma simples "parte do movimento circular", por mais pequena que seja, "ainda é tempo", não sendo por isso necessário esperar pela revolução completa para o termos; e depois, e de uma forma mais grave, que Platão identifica afinal o tempo com o movimento, porque o que ele conta são as próprias revoluções." (REIS, 2001, p. 468).

22 Como destacou Silvia Gastaldi numa nota de pé de página: "Além disso, ele reivindica abertamente essa função, como se depreende da Apologia: suas contínuas solicitações diante dos cidadãos são comparadas às picadas de uma mosca no corpo de um cavalo de raça nobre, impotente, mas preguiçoso." (GASTALDI, 2015, p. 157).

${ }^{23}$ Kant também foi acusado pelo Rei da Prússia - Frederico Guilherme II, mas não condenado. (KANT, 2008).
} 
Seus concidadãos não podem perceber seu convite para examinar seus valores, sua maneira de agir, para tomar cuidado consigo mesmo, como também pra uma ruptura radical com a vida cotidiana, com os hábitos e as convenções da vida corrente, como o mundo que Ihes é familiar. Mas, de outro lado, esse convite para tomar cuidado consigo mesmo não será um apelo para afastar-se da cidade, fora do mundo, átopos, ou seja, que é estranho, inclassificável, absurdo? Sócrates não será o protótipo da imagem tão disseminada e, por outro lado, afinal tão falsa do filósofo que foge das dificuldades da vida, para refugiar-se em sua boa consciência. (HADOT, 1999, p. 66).

Sócrates não se refugia na boa consciência, mas enfrenta opinião da maioria examinando as questões postas por meio da razão, como um dever para consigo mesmo, com os outros e para com as leis da cidade que o educou para quem sabe muda-la, na medida em que se resiste ao que está posto (HADOT, 1999, p. 67). Como argumentou Silvia Gastaldi em seu artigo sobre "O filósofo e o político: gêneros da vida rivais ou conciliáveis":

Nesta situação, Sócrates, embora considere ser um único verdadeiro homem político capaz, por meio de suas críticas ao regime em vigor, de agir na qualidade de médico e não de servidor, se mantém distante da política ativa. Ele se limita - como observa Cálicles - a transmitir sua mensagem ética a poucos jovens, mantendo-se de lado. (485 D). (GASTALDI, 2015, p. 159).

A mensagem ética e política de Sócrates na polis é para poucos jovens, que se mantém ao seu lado, apesar do seu tom crítico ao regime político em vigor, pois na perspectiva de Sócrates não podemos nos dobrar as opiniões da maioria.

Retornando, a reposta indicada por Sócrates parece um desvio de rota, ao começar um diálogo sobre a opinião da maioria que para Critão é significativo e Sócrates não, pois não devemos nos preocupar com a opinião da maioria, mas sim com as considerações dos melhores. Contudo, o problema da maioria é categorizado como a questão que leva ao mal, quando os homens são "vítimas de calúnias" e do "povo/criança mal-educada" (ROMANO, 2001, p. 23) que pensa sua vontade sem obstáculo na democracia gerando com isso "o excessivo arbítrio dos indivíduos" que conduz o Estado ao poder do "mando tirânico, o exato oposto da democracia" (ROMANO, 2001, p. 23). Neste sentido, Sócrates reitera que a maioria age "por mero acaso". Na perspectiva aristotélica, agir pelo acaso, é agir sem pensar ${ }^{24}$ (ARISTÓTELES, Metafísica, Livro I, 981a 5). Aristóteles complementa na Ética à Nicômaco:

Toda arte e toda indagação, assim como toda a ação e todo propósito, visam a algum bem; por isto foi dito acertadamente que o bem é aquilo a que todas as coisas visam. Mas nota-se uma certa diversidade entre as finalidades; algumas são atividades, outras são produtos distintos das atividades de que resultam; onde há finalidade distintas das ações, os produtos são por natureza melhores que as atividades. Mas como há muitas atividades, artes e ciências, suas finalidades também são muitas; a finalidade da medicina é a saúde, a da construção naval é a nau, a da estratégia é a vitória, a da economia a riqueza. Onde, porém, tais artes se subordinam a uma única aptidão - por exemplo, da mesma forma que a produção de rédeas e as outras artes relativas a acessórios para a montaria se subordinam sucessivamente a outras - as finalidades das artes principais devem ter precedência sobre todas as finalidades subordinadas, com efeito, é por causa daquelas que estas são perseguidas. Não haverá diferenças alguma no caso de as próprias atividades serem as finalidades das ações ou serem algo distinto delas, como ocorre com as artes e ciências mencionadas. (ARISTÓTELES, Metafísica, Livro I, 1094 a).

\footnotetext{
24 “Aristóteles é de opinião de que a grande maioria das pessoas não alcança deliberar com autonomia sobre o que é o bom fazer, vivendo ao contrário sob impulso momentâneo, precisando assim ser constantemente educada pelo Estado. Para aquelas pessoas que não possui a capacidade deliberativa, só resta a indicação vaga de que, em relação à afecção e à inspiração que rege àquela, não deve nem de mais nem de menos." (WOLF, 2010, p. 74).
} 
Vale lembrar que Aristóteles ${ }^{25}$ segue os pressupostos de Platão ao salientar que agir sem pensar é uma vida sem sentido ou sem finalidade, proporcionando com isso o (kaos) Xáoc. Por isso, devemos entender que as finalidades que desejamos são escolhas que realizamos a cada momento, que somos provocados pelas ações que devem promover o bem e o bem melhor da Pólis ${ }^{26}$ e não a sua destruição, como a destruição das leis como estava propondo Critão.

[...], o que Sócrates proclama como seu dever, como aquilo pelo que deve a tudo sacrificar, mesmo sua vida, é a obediência às leis da cidade, as "Leis" personificam que, no Críton, exortam Sócrates a não se deixar levar pela tentação de evadir-se da prisão e fugir para longe de Atenas, fazendo-o compreender que sua salvação egoística será uma injustiça para com Atenas. (HADOT, 1999, p. 67).

Dentro desta perspectiva, podemos voltar ao texto e a insistência de Critão na ideia de convencer Sócrates de fugir da prisão e livrar-se da penalidade da morte, pois o processo de corrupção para livrá-lo da prisão já estava no arcabouço das relações com os sicofantas. A continuidade da proposta era que Sócrates poderia viver em segurança na Tessália como hóspede sem que ninguém o prejudicasse. Assim, Sócrates não abandonaria os filhos e a educação dos mesmos. Critão conclui o seu argumento de que passou a "tempo de refletir" e que "se tardarmos mais algum tempo, nada se poderá fazer; perderemos a última oportunidade"27 (PLATÃO, Critão 67 ou 46 a). Sócrates educadamente argumenta que vai examinar a questão proposta por Critão, adiantado que não pode renegar os seus argumentos no passado, por causa da sua condenação, do temor da morte e da pressão da maioria que o condenou, mas que deveria ser coerente com a sua vida na polis - que é viver sem se corromper, pois, "o que mais importa não é viver, porém viver bem" (PLATÃO, Critão 2007, 70 ou 48 b) de forma justa e boa, sem realizar o mal, recusando assim, promover a justiça com a injustiça ou o bem com o mal. Como salientou Hannah Arendt, em Verdade e Política:

A história do conflito entre moral e política é antiga e complexa, e nada seria ganho com simplificação ou denuncia moral. No transcurso da história, os que perseguem e os que contam a verdade tiveram consciência dos riscos de suas atividades; enquanto não interferiam no curso do mundo, eram cobertos de ridículo, porém aquele que forçasse seus concidadãos a levá-lo a sério, procurando pô-lo a salvo da falsidade e ilusão, encontra-se em perigo de vida: "Se eles pudessem por as mãos em [tal] homem... o matariam", diz Platão na derradeira sentença da alegoria da caverna. (ARENDT, 1992, p. 285).

Neste sentido, Sócrates em seu diálogo com a Pólis reafirma o princípio de cumprir com a sua palavra e as suas ações como cidadão que deve agir com o consentimento da Pólis sem prejudicá-la em nada, pois as leis e o governo da Pólis não devem ser destruídos, mas vividos

\footnotetext{
${ }^{25}$ Contudo vale destacar que: "Aristóteles, ao invés, não está de acordo com o mestre nesse ponto: não são os filósofos que devem governar, mas os homens prudentes, que conhecem as situações particulares que têm a experiência da vida" (BERTI, 2014, p. 78).

${ }^{26}$ Como Platão argumentou pela boca do Ateniense no livro As Leis: "Naturalmente nos será forçoso obrigar os guardiães de nossa constituição divina a observarem meticulosamente, em primeiro lugar, qual é o elemento idêntico que permeia todas as quatros virtudes, e que considerando-se que existe como unidade na coragem, temperança, justiça e sabedoria - possa com justeza ser denominado, como o afirmamos, pelo único nome virtude. Esse elemento, meus amigos, precisa ser por nós, se o permitis, retido com muita firmeza, sem que nos escape, até que tenhamos explicitado adequadamente a natureza essencial do objeto a ser visado, que exista por natureza como unidade, como um todo, como ambos, ou de uma outra forma. Ademais, se nos escapar, ser-nos-á possível supor que compreenderemos apropriadamente a natureza da virtude quando somos incapazes de estabelecer se é múltipla, quádrupla ou una? Consequentemente, se seguirmos nossas próprias diretrizes, conceberemos algo, de um modo ou outro, para que esse conhecimento exista em nosso Estado. Se optarmos, todavia, por deixá-lo de lado completamente, assim poderemos agir." (PLATÃO, As Leis, p. 506).

${ }^{27}$ Oportunidade aqui é um embuste ou uma falácia.
} 
com justiça - mesmo correndo perigo de vida ${ }^{28}$. Como destacou Solange Norjose no artigo Platão: a cidade das leis e o poder do rumor:

Nesse sentido, pensamos que Platão retoma sua teoria da mímesis nas Leis, para demonstrar, por um lado, que o legislador cria os melhores nomoi sempre voltado para a justiça, e por outro lado, como sua autoridade efetiva a aplicação dos nomoi na produção dos coros e seus efeitos na comunidade. O filósofo parte da seguinte consideração: o que é agradável ocorre por causa de sua essência, da sua retidão e por sua utilidade, por isso os alimentos que agradam pelo prazer de ser ingerido, de fato o que realmente importa é sua qualidade de ser saudável, por isso será necessário e útil (Lg., II, 667b-c). Portanto, é preciso saber a natureza do modelo, depois a maneira correta de imitá-lo e enfim seu valor ou utilidade (NORJOSE, 2012, p. 165).

Neste, sentido, a Pólis é responsável pela educação dos conterrâneos de Sócrates e o cidadão ateniense nada mais é do que o desdobramento da sua vida na pólis e das suas leis ${ }^{29}$, como o bem comum e público de todos, que realiza o ordenamento da vida dos homens que devem reverenciar as leis e não destruí-las com um cidadão ridicularizado pelos demais da sua "cidade" que vaga pelo mundo como um animal selvagem e rastejante, sem lei, e conforme a circunstância, como um camaleão, mudando de aparências, por não estimar o valor a justiça e a virtude das leis, que mantém as posturas dos homens mediante as leis, a pólis e o Hades que é o caminho indicado pela divindade.

Como argumentou Thomas Alexander Szlezák: "no Critão, Sócrates faz as leis de Atenas falarem por si mesmas, e elas lhes oferecem argumentos com que ele poderá se defender no além perante os governantes de lá". (SZLEZÁK, 2009, p. 234). Como arremata Platão em Fedão:

Para a raça dos deuses não é permitido passar os que não praticaram a Filosofia nem partiram inteiramente puros, mas apenas os amigos da Sabedoria. É por isso, meus caros Símias e Cebes, que os verdadeiros filósofos se acautelam contra os apetites do corpo, resistem-lhes e não se deixam dominar por eles; não tem medo da pobreza nem da ruína de sua própria casa, como a maioria dos homens, amigos das riquezas, nem temem a falta de honrarias e a vida inglória, como se dá com os amantes do poder e das distinções. Não é essa a razão de se absterem de tudo? (PLATÃO, Fedão, 82c).

Tal perspectiva arrematada em Fedão nos lembra que a vida do filósofo não deve pautar o seu pensamento e a sua ação como cidadão da Pólis por aqueles que se reduzem aos amantes do poder e das distinções aparentes e das falaciosas honrarias que nos deixa afetados pelo medo que nos assolam nos movimentos passageiros e mutáveis da vida. Desse modo, Filósofo deve:

\footnotetext{
28 [...], a vida do corajoso triunfa sobre a do covarde e do sábio sobre do tolo. Concluímos que o primeiro conjunto de vidas se classifica como mais prazeroso que segundo, quer dizer, as vidas de temperança, de coragem, de sabedoria e de saúde são mais prazerosas que a vidas do licencioso, do covarde, do tolo e do enfermo. Em suma, a vida que conta com a excelência do corpo e da alma comparada àquela que abriga o vício não é apenas mais prazerosa como também é grandemente superior em beleza, retidão, virtude e boa reputação, de modo a fazer com que aquele que vive, viver sempre muito mais feliz do que quem vive a vida oposta (PLATÃO, As Leis, p. 210).

${ }^{29}$ Contudo, vale a pena recordar o argumento de Cornelius Castoriadis no seminário de 19 de fevereiro de 1985 Sobre o Político de Platão, mesmo não concordando totalmente com ele: "[...], Platão é completamente indiferente em relação a Atenas, ele crítica, e não somente à democracia. Ele mantém uma espécie de orgulho racial, se nos permitem dizer, que é encontrado no final das leis, quando o Lacedemônio e o Cretense concordam entre si que não teriam conseguido resolver o problema da boa cidade se não houvessem sido acompanhados pelo Ateniense durante essa longa caminhada filosófica - caminhada em sentido próprio e figurado. Ele mantém portanto esse ponto de honra, mas, no que diz respeito ao conteúdo e à substância de Atenas, à criação histórica ateniense, ele a detesta. De qualquer forma, ele simplesmente utiliza a sua situação de cidadão ateniense para beneficiar-se do que aprendeu, para beneficiar-se de Sócrates, que é um filho da cidade, para beneficiar-se da paideia que se expande em Atenas, para beneficiar-se de sua própria posição. E, por fim, para fundar a sua escola nos jardins de Academus, beneficiando-se do liberalismo, do amor pela liberdade dos atenienses que, mais uma vez, permitem que alguém abra um ensino público que crítica a sua cidade em vez de mandar mata-lo imediatamente como teriam feito os éforos em sua amada Esparta." (CASTORIADIS, 2004, p. 29).
} 
Não, de fato; a alma do filósofo não raciocina desse jeito nem pensa que a filosofia deva libertá-la, para depois de livre, entregar-se de novo aos prazeres e as dores e voltar a acorrentar-se, deixando írrito seu esforço anterior e como que empenha em fazer o inverso do trabalho de Penélope em sua teia. Ao contrário: alcançando a calmaria das paixões e guiando-se pela razão, sem nunca a abandonar, contempla o que é verdadeiro e divino e que paira acima das opiniões, certa de que precisará viver assim a vida toda, para depois da morte, unir-se ao que lhe for aparentado e da mesma natureza, liberta das misérias humanas. Não é de admirar, Símias e Cebes, que uma alma alimentada desse jeito e com semelhante ocupação não tenha medo de desmembrar-se quando se retira do corpo, e de ser dispersada pelos ventos, dissipando-se de todo, sem vir a ficar em parte alguma. (PLATÃO, Fedão, 84a-b).

A razão deve ser a perspectiva do filósofo e não as paixões e as opiniões, pois como em Fedão ou Critão, podemos argumentar que a resposta de Sócrates é que ele é filho da pólis e como filho deve viver o ordenamento da pólis que o educou, criou e o preparou para o exame criterioso e crítico do pensar que é completamente avesso aos processos de doutrinação e dogmatismo. Filosofia, neste sentido é o pensamento crítico da vida na pólis na vivência da justiça, do belo, do bom e do verdadeiro ${ }^{30}$. Nos ensina em tempos de crises e oportunidades que a atividade do pensamento é "ofício perigoso" (CANFORA), tanto quanto "o perigo de não alcançar a atitude correta do dialético no trato com os "logoi" está sempre à espreita" (SZLEZÁK, 2009, p. 235).

Além disso, como argumentou Platão na República:

[...] aquele que se tornou filósofo e saboreou a doçura e a felicidade que proporciona a posse da sabedoria, que viu bem a loucura da multidão e como não há por assim dizer ninguém que faça algo de sensato no domínio dos negócios públicos, aquele que sabe não possuir aliado com o qual pudesse ir em socorro da justiça sem perder-se, mas que ao contrário, como um homem caído no meio de animais ferozes, que nem se dispusesse a participar de seus crimes, nem se sentisse capaz sozinho, resistir a este seres selvagens, pela certeza de vir a perecer muito antes de poder servir à pátria e aos amigos, sem proveito algum nem a si mesmo nem aos outros: penetrando por tais reflexões, mantém-se quieto e ocupa-se de seus próprios afazeres; semelhante ao viajor que, durante uma tempestade enquanto o vento levanta turbilhões de poeira e chuva, se abriga atrás de um pequeno muro, ele vê os outros manchados de iniquidades e é feliz se consegue viver sua vida neste mundo, isento de injustiça e atos ímpios, e abandoná-la, sorrindo e tranquilo, com uma bela esperança. (PLATÃO, A República, 496 d-e).

A esperança do filósofo é a de conduzir a vida do cidadão "a boa direção", ao "bom hábito" e aos "bons exercícios" do corpo e da reflexão "teorética" que podem levá-lo à ciência da virtude divina (Cf. PLATÃO, A República, 518d; 519a) ${ }^{31}$. Platão sabia que viver na pólis era viver entre as bestas feras, os corruptores, os injustos e os iníquos governos criminosos que provocavam tempestades e chuvas fortes ${ }^{32}$, seja pelas suas ações interesseiras e desmedidas ou pelas

\footnotetext{
${ }^{30}$ [...], até a investigação acerca do homem político deve ser finalizada a 'tornar quem investiga melhor dialético em todos os aspe-

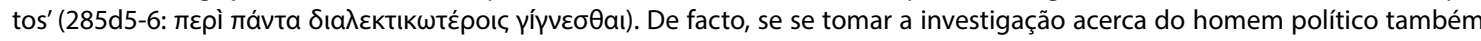

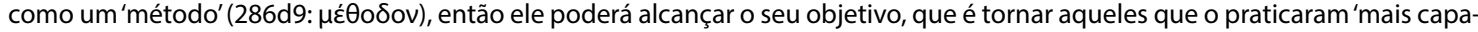

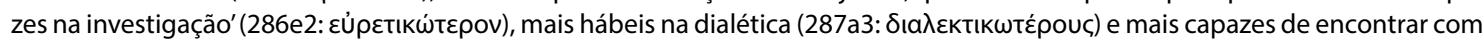

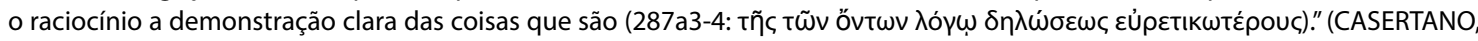
2018, p. 183).

${ }^{31} \mathrm{Na}$ expressão do Enrico Berti extraída de Platão aquisição da "ciência da virtude divina" é o "caminho para cima", isto é uma verdadeira epistéme (BERTI, 2013, p. 124).

32 Segundo Hegel “[...], a filosofia jónica entrou [em cena] com a decadência dos Estados jónicos da Ásia Menor. Sócrates e Platão já não tinham qualquer regozijo com a vida do Estado ateniense que estava abrangida pela sua decadência; Platão procurou pôr de pé algo de melhor junto de Dionísio. Entrou, assim, em Atenas, com a deterioração do povo ateniense, o tempo em que a filosofia aí apareceu." (HEGEL, 1995, p. 102).
} 
mãos da opinião da maioria que nem sempre se pautava pela razão e pelas leis da polis que visa o bem comum e público de todos. Como podemos verificar na República:

[...], que a lei não se preocupa em assegurar felicidade excepcional a uma classe de cidadão, mas se esforça por realizar a ventura da cidade inteira, unindo os cidadãos pela persuasão ou coerção, e levando-os a partilhar em comum das vantagens que cada classe pode proporcionar à comunidade; e que, se ela forma tais homens na cidade, não é para lhes dar a liberdade de se voltarem para o lado que lhes aprouver, mas para fazê-los concorrer ao fortalecimento da cidade. (PLATÃO, A República, 520a).

Enfim, a razão deve ser a guia mestra que vem sempre em socorro ${ }^{33}$ do filósofo, em contraposição as pelas paixões estomacais que não conduz ao caminho do bem, do verdadeiro, do justo e da liberdade que filósofo experimentou e saboreou como expressão da feliz vida na cidade que é percebida como uma unidade ${ }^{34}$ (PLATÃO, A República, 524e). Unidade que transborda em sabedoria adquirida à luz da razão que pensa "uma cidade bem governada, pois nesta cidade só hão de comandar os que são verdadeiramente ricos, não de ouro, mas dessa riqueza de que o homem precisa para ser feliz: uma vida virtuosa e sábia." (PLATÃO, A República, 521a). Como Sócrates apresentado por Critão, que viveu e foi coerente com a sua vida e não fugir de si mesmo e da morte sem sentido na vida da Pólis que o educou pelas leis e para viver bem as leis ${ }^{35}$, mas a partir do "vento do pensamento" que são como "um furacão que varre para longe todos os signos estabelecidos com que os homens se orientam no mundo; traz a desordem às cidades e confunde os cidadãos, especialmente os mais jovens." (ARENDT, 1993b, p. 159-160).

Assim ratificamos que:

Se"não vale a pena viver uma vida sem reflexão", então o pensar acompanha o viver, quando se envolve com conceitos como justiça, felicidade, moderação, prazer, como palavras que designam coisas invisíveis que a língua nos ofereceu para explicar o significado de tudo o que acontece em nossa vida e quando estamos vivos. Sócrates dá a essa busca o nome de eros, um tipo de amor que antes de tudo uma falta - deseja o que não possui - e que é o único assunto de que Sócrates se diz conhecedor. Os homens amam a sabedoria e fazem filosofia (philosophein) por não serem sábios, assim como amam a beleza e, por assim dizer, "fazem o belo" (philokalein, como diz Péricles) por não serem belos. (ARENDT, 1993b, p. 160).

Contudo, essa busca incessante do filósofo na pólis pelos assuntos humanos nos coloca a seguinte questão: o que nos da vontade de fazer o bem? E o que consideramos justo e bom quando devemos agir para o bem comum ao meditarmos sobre o texto do Critão pelas leituras arendtianas? O que nos da vontade de fazer o bem e de considerar o que é justo e bom quando agimos para promover o bem comum é o thaumadzein, isto é "o espanto daquilo que é como é" (ARENDT, 1993b, p. 115), pois quando pensamos somos capazes e recolher no nosso "interior" $\mathrm{e}$ fazer "ressoar essas palavras, impedindo-me de atender a tudo mais" (PLATÃO, 2007, p. 79 ou XVII e). Deste modo, o "espanto admirativo" é a possiblidade de excluir o "mal tal como ele se desdobra" na nossa vida quando pensamos e amamos a beleza, a justiça e a sabedoria como

\footnotetext{
${ }^{33}$ Sobre esse assunto consultar o capítulo sobre Fedro, "O desenvolvimento do Diálogo". (SZLEZÁK, 2009).

${ }^{34}$ Como argumentou Hegel a "[...] finalidade da vontade verdadeira, o bem, o justo, onde eu sou livre, algo de universal, e [onde] os outros também são livres, também são Eus, iguais a mim (e, portanto, [onde] estão postas uma relação de livres a livres e, por conseguinte, determinações, leis, essências da vontade universal, [uma] constituição jurídica) - esta liberdade só a encontramos no povo grego. Portanto, aí começa a filosofia." (HEGEL, 1995, p. 155-156).

${ }^{35}$ Como descreveu Pierre Hadot em "a figura de Sócrates" na obra O que é filosofia antiga? "Merleau-Ponty ressaltou bem:'Sócrates tem uma maneira de obedecer que é uma maneira de resistir', submeter às leis para provar, no interior da cidade, a verdade de sua atitude filosófica e o valor absoluto da intenção moral. Não é necessário dizer, então, com Hegel, que 'Sócrates retira-se para si mesmo para buscar a justiça e o bem', mas com Merleau-Ponty, 'ele pensava que não se pode ser justo sozinho, do mesmo modo como o ser sozinho cessa de ser"'. (HADOT, 1999, p. 67).
} 
possibilidade de examinar e investigarmos o que nos move quando agimos com dignidade e confiança (ARENDT, 1995, 135) como o cidadão da Polis.

\section{Considerações finais}

Ressaltamos que a filosofia em "tempos sombrios" é um espaço aberto para pensar os movimentos conservadores e contrários ás forças democráticas, mesmo sendo Platão um crítico feroz da democracia ateniense, que na sua visão se desenhava com forças obscurantistas e com a roupagem da oligarquia disfarçada de democrática, mas que na realidade manipulava a maioria da população por meio da opinião que não falava aos ditames da razão, das paixões da população deseducada e presa as sombras imagéticas do fundo da caverna, mas que hoje se avoluma pelo poder mediático que explora massivamente e contraditoriamente a opinião da maioria como se fosse democraticamente válida para todos.

Paradoxalmente o pensamento conservador surge das sombras para se instalar nas sombras imagética da caverna que torna o cidadão brasileiro prisioneiro e acorrentado do pescoço aos pés. Fios invisíveis das imagens virtuais das redes sociais sem a mediação do pensar, das imagens sem o tempo da reflexão, do imediato sem a "paciência do conceito", do bom senso e da fé pública, que deveria nos indicar estarmos juntos no mundo para partilhar a construção e organização de uma cidade feliz.

Em síntese, as nossas esperanças são de enfrentamento dos problemas com postura, coragem e escolhas deliberadas em meio a tantas paixões e opiniões que nos afetam, pois nos é exigido, nestes tempos que vivemos, pensar, decidir e agir com abertura para o mesmo e o outro. Sem excluí-lo da convivência crítica e alegre que promove a liberdade e combate o medo, que nos paralisa e nos coloca em posição de ataque violento contra nós mesmo e o outro.

Assim, como apresentado em Critão, Sócrates pensou e agiu em consonância com as leis, da cidade que o educou para a liberdade de viver bem a unidade da vida na cidade que deixa as leis falarem por si, mesmo em tempos de obscurantismo, fanatismo religioso e sombrios das cavernas que mercantilizam os corpos e mentes que aprisionam a nossa população deseducada para pensar o bem comum e público da nossa sociedade e Estado - devemos assumir um compromisso com o pensar atuante e vigoroso que nos arranca dos nossos lugares para viver e morrer pela Pólis, que o dinheiro não compra com malas de propinas e corrupção, que corre de mãos e mãos dos nossos governantes sem um projeto comum de Estado soberano para a população.

Neste sentido, a reflexão sobre a filosofia em "tempos sombrios": a leitura de Critão sobre Sócrates na pólis diante das leis e da opinião da maioria - um olhar arendtiano é de extrema importância para os nossos tempos, pois nos provoca a pensar que "dizer a verdade dos fatos abrange muito mais que as informações diárias suprimidas pelos jornalistas" (ARENDT, 1992, p. 322) e outros aloprados da mídia social que muitas vezes parecem nada mais do que sentimentos (opiniões) ou diarreias de palavras que a maioria adere sem o exame criterioso e diário do pensamento que acompanha a nossa vida.

\section{Referências}

ARENDT, Hannah. Homens em tempos sombrios. Tradução de Denise Bottmann. São Paulo: Companhia das Letras, 1987. 
ARENDT, Hannah. Entre o passado e o futuro. Tradução de Mauro W. Barbosa de Almeida. São Paulo: Editora Perspectiva, 1992.

ARENDT, Hannah. Lições sobre a filosofia política de Kant. Tradução de André Duarte de Macedo. Rio de Janeiro: Relumé Dumará, 1993a.

ARENDT, Hannah. A dignidade da política. Ensaios e conferências. Tradução de Helena Martins et. al. Rio de Janeiro: Relume-Dumará, 1993b.

ARENDT, Hannah. A vida do Espírito. O pensar, o querer e o julgar. Tradução de Antônio Abranches; Cesar Augusto R. de Almeida; Helena Martins. Rio de Janeiro: Relumé Dumará, 1995.

ARENDT, Hannah. Crise da República. Tradução de José Volkmann. São Paulo: Editora Perspectiva, 1999.

ARISTOTELES. Ética a Nicômacos. Tradução de Mario da Gama Kury. Brasília: Editora Universidade de Brasília, 1985, 1999.

BERTI, Enrico. Novos estudos aristotélicos III. Filosofia prática. Tradução de Élcio De Gusmão Verçosa Filho. São Paulo: Edições Loyola, 2014.

BERTI, Enrico. Contradição e dialética nos antigos e nos modernos. Tradução de José Bortolini. São Paulo: Paulus, 2013.

BRISSON, Luc. PRADEAU. Jean-Francois. As leis de Platão. Tradução de Nicolás Nyimi Campanário. São Paulo: Edições Loyola, 2012.

CANFORA, Luciano. Um ofício perigoso. A vida cotidiana dos filósofos gregos. Tradução de Nanci Fernandes e Maria Bertoli. São Paulo: Perspectiva, 2003.

CANFORA, Luciano. O mundo de Atenas. Tradução de Frederico Carotti. São Paulo: Companhia das Letras, 2015.

CANFORA, Luciano. Crítica da retórica democrática. Tradução de Valéria Silva. São Paulo: Estação Liberdade, 2007.

CASERTANO, Giovanni. Dialética. In: CORNELLI, Gabriele; LOPES, Rodolfo (Orgs.). Platão. Coimbra: Imprensa da Universidade de Coimbra; São Paulo: Editora Paulus, 2018. Disponível em:///C:/Users/notebook/Documents/textos\%20antigos/Platao.pdf. Acesso em: 2 nov. 2018.

CASTORIADIS, Cornelius. Sobre O político de Platão. Tradução de Luciana Moreira Pudenzi. São Paulo: Edições Loyola, 2004.

ERLER, Michel. "Sócrates na Caverna": as argumentações como terapia das paixões no Górgias e no Fédon. In: MIGLIORI, Maurizio; VALDITARA, Linda M. Napolitano (Orgs.). Tradução de Silvana Cobuicci Leite e Élcio de Gusmão Verçosa Filho. São Paulo: Edições Loyola, 2015.

FILHO, Gérson Pereira. As múltiplas linguagens no diálogo as Leis, de Platão. Revista de Estudos Filosóficos e Históricos da Antiguidade - IFCH-UNICAMP. Campinas, ano XIX, n. 28 jun. /dez. 2014. Disponível em: https://www.ifch.unicamp.br/ojs/ index.php/cpa/issue/view/101. Acesso em: 6 nov. 2018.

GASTALDI, Silvia. O filósofo e o político: gêneros de vida rivais ou conciliáveis? In: MIGLIORI, Maurizio; VALDITARA, Linda M. Napolitano (Orgs.). Plato ethicus. A filosofia é vida. Tradução de Silvana Cobuicci Leite e Élcio de Gusmão Verçosa Filho. São Paulo: Edições Loyola, 2015.

HADOT, Pierre. O que é a filosofia antiga? Tradução de Dio Davi Macedo. São Paulo: Loyola, 1999.

HEGEL, G.W.F. Introdução às lições sobre a história da filosofia. Tradução de José Barata-Moura. Porto: Porto editora, 1995.

KANT, Immanuel. A resposta à pergunta: "o que éo iluminismo?"Tradução de Artur Morão. Covilhã: Universidade de BAEIRA Interior, 2008. 
KANT, Immanuel. O conflito das faculdades. Tradução de Artur Morão. Covilhã: Universidade de BAEIRA Interior, 2008.

MARTINS, António Manuel. Filosofia e Política em Platão. Humanitas. Instituto de Estudos Clássicos da Faculdade de Letras da Universidade de Coimbra. v. XLVII -1995. Disponível em:///C:/Users/notebook/Documents/textos\%20antigos/Humanitas 47.1_artigo25.pdf. Acesso em: 2 nov. 2018.

NORJOSA, Solange. Platão: a cidade das leis e o poder do rumor. In: CORNELLI, Gabriele. (Org). Representações da cidade antiga: categorias históricas e discursos filosóficos. 2012. Disponível em: https://digitalis.uc.pt/pt-pt/livro/platão_cidade_das_leis_e_o_poder_do_rumor. Aceso em: 29 out. 2018.

OLIVEIRA, Richard R. Dimiurgia política. As relações entre a razão e a cidade nas Leis de Platão. São Paulo: Edições Loyola, 2011.

PLATÃO. Fedão: sobre a alma. Tradução de Carlos Alberto Nunes. Belém: EDUFPA, 2002.

PLATÃO. Teeteto. Crátilo. Tradução de Carlos Alberto Nunes. Belém: EDUFPA, 2001.

PLATÃO. Protágoras. Górgias. Fedão. Tradução de Carlos Alberto Nunes. Belém: EDUFPA, 2002.

PLATÃO. A República. J. Guinsburg organizador e tradutor. São Paulo: Perspectiva, 2006.

PLATÃO. Critão, Hipias Maior. Tradução de Carlos Alberto Nunes. Belém: EDUFPA, 2007.

PLATÃO. As Leis, ou da legislação e epinomis. Tradução de Edson Bini. Bauru: Edipro, 1999.

PERINE, Marcelo. Princípios. In: CORNELLI, Gabriele; LOPES, Rodolfo (Orgs.). Platão. Coimbra: Imprensa da Universidade de Coimbra; São Paulo: Editora Paulus, 2018. Disponível em:///C:/ Users/notebook/Documents/textos\%20antigos/Platao.pdf. Acesso em: 2 nov. 2018.

REIS, José. O tempo de Platão a Plotino. Revista de História das ideias. v. 22, 2001. Disponível em:///C:/Users/notebook/Downloads/201811521217690outfile.pdf. Acesso em: 2 nov. 2018.

ROMANO, Roberto. O caldeirão de Medéia. São Paulo: Perspectiva, 2001.

SZLEZÁK, Thomas Alexander. Platão e as escrituras da filosofia. Análise de estrutura dos diálogos da juventude e da maturidade à luz de um novo paradigma hermenêutico. Tradução de Milton Camargo. São Paulo: Loyola, 2009.

TRABATTONI, Franco. Platão. Coimbra: Imprensa da Universidade de Coimbra; São Paulo: Editora Annablume, 2017.

VERGETTI, Mario. Ética e Política. In: CORNELLI, Gabriele; LOPES, Rodolfo (Orgs.). Platão. Coimbra: Imprensa da Universidade de Coimbra; São Paulo: Editora Paulus, 2018. Disponível em:///C:/ Users/notebook/Documents/textos\%20antigos/Platao.pdf. Acesso em: 2 nov. 2018.

WOLF, Úrsula. A Ética a Nicômaco de Aristóteles. Tradução de Enio Paulo Giachini. São Paulo: Edições Loyola, 2010.

\section{Sobre o autor}

\section{Daner Hornich}

Doutor em Filosofia. Centro UNISAL de São Paulo - Unidade de Americana. 